\title{
CONCESSIONÁRIA DE SERVIÇO PÚBLICO - BENS PÚBLICOS - DIREITO
}

DE USO

Uso de sub-solo de faixas de domínio de rodovias e vias públicas por empresas concessionárias de serviços públicos; bens públicos e seu uso; servidão administrativa, direito restritivo de passagem e preço; serviço público na Constituição de 1988 e a falsa "privatização de serviço público"

A Associação Brasileira das Empresas Distribuidoras de gás Canalizado - ABEGÁS encaminhou-me a seguinte

"Consulta

A Associaçāo Brasileira das Empresas Distribuidoras de Gás Canalizado - ABEGÁS, entidade sem fins lucrativos que congrega $e$ representa as empresas concessionárias da distribuição de gás canalizado dos vários Estados, considerando a situação exposta a seguir, de uso de práticas onerosas na utilização de faixas de domínio de rodovias e de vias públicas, fato esse que altera conceitos até então praticados na utilizaçāo de forma geral do domínio público, vem solicitar de V.S. a análise e emissão de parecer jurídico.

Situação

Até recentemente. a União e os Estados, através respectivamente do Departamento
Nacional de Estradas de Rodagem - DNER e dos Departamentos de Estradas de Rodagem - DERs, concediam autorização, em caráter nāo oneroso, para travessias subterrâneas das tubulações de gás canalizado em rodovias. bem como para ocupação das faixas de domínio dessas rodovias, na implantação de gasodutos e redes de distribuição de gás. Todavia, com o novo cenário de concessão da operação das rodovias à iniciativa privada ('processos de privatização"), tanto as novas empresas concessionárias de exploração dos serviços, como os órgāos da administraçāo pública (DNER e DERs) vem impondo, às empresas concessionárias de distribuição de gás canalizado, seja a utilizaçāo das faixas de domínio procedida em caráter oneroso.

O DNER utiliza-se, como justificativa para cobrança, do disposto no inciso VI do artigo 
$4^{2}$ do Decreto Federal n $512 / 69$ que estabelece 'também como receita para esse órgão o produto da exploração e arrendamento de bens patrimoniais do seu acervo não necessários a seus serviços ou destinados à serventia pública'. No caso das novas empresas concessionárias, a justificativa é o disposto nos contratos de concessão firmados, que estabelecem que 'fica facultado à concessionária explorar outras fontes de receitas sejam elas complementares, acessórias, ou alternativas à fonte principal ou, ainda explorar fontes de receitas provenientes de projetos associados'. Há todavia divergências entre o DNER e as concessionárias quanto à competência e destino da arrecadação: ao órgāo público ou à concessionária. Nos Estados, os DERs também tem-se manifestado pela adoção da prática onerosa na utilização das faixas de domínio das rodovias estaduais.

Não há regulamentação quanto à prática em si, sendo que os valores cogitados de cobrança por parte das concessionárias de exploração das rodovias têm sido os mais diversos, sem uma base para análise e discussão e sem maiores definições dos órgãos públicos envolvidos.

No caso particular do setor elétrico, conforme disposto no Decreto Federal n 84.398/80, alterado pelo Decreto $\mathrm{n}^{2} 86.859 / 82$, a utilização das faixas de domínio de rodovias e de terrenos de domínio público por linhas de transmissão e distribuição de energia elétrica é isenta de qualquer cobrança.

Para o setor de telecomunicações, com a perspectiva de forte utilização das faixas de domínio das rodovias na implantação de projetos de fibras óticas, o DNER vem publicando Portarias estabelecendo ocupação onerosa das faixas de domínio das rodovias federais para a implantação de redes digitais e torres de transmissão.

Para as travessias de rodovias federais, o DNER recentemente publicou a Portaria de $\mathrm{n}^{2} 410$, de 17.07.99, estabelecendo à cobrança de licença à título oneroso aos órgãos da administração pública, concessionária de serviço público privado e de terceiros para utilização das faixas de domínio'. A essa utilização corresponde uma cobrança de remuneração cuja composição é indicada na Portaria.

No caso de ferrovias, o Regulamento dos Transportes Ferroviários, aprovado pelo Decreto $\mathrm{n}^{\mathrm{Q}} 1.832 / 96$, determina que não poderá haver impedimento de travessia estabelecendo encargos quanto a construção, conservação e vigilância, que 'caberāo a quem executar o serviço mais recente'. O Regulamento é omisso quanto à utilização onerosa ou não das faixas de domínio.

Prefeitos de cidades dos Estados de São Paulo e Santa Catarina têm manifestado intenções de cobrança de algum tipo de remuneração pela utilização de vias públicas. Recentemente, a Prefeitura do Município de São Paulo, através do Decreto 38.139 , de 01.07.99, estabeleceu a utilização onerosa do uso das vias públicas inclusive do espaço aéreo e do subsolo e das obras de arte para a implantação, instalação e passagem de equipamentos urbanos destinados à prestação de serviços de infra-estrutura urbana'.

A distribuição de gás canalizado carateriza serviço público, consubstanciando a forma de se levar, nas cidades, o gás aos consumidores, através de tubulaçōes assentadas no subsolo das vias públicas, da mesma forma que a distribuição de água e de outros serviços públi$\cos$. A utilização do subsolo de faixas de domínio de rodovias e ferrovias também tem sido prática no fornecimento de gás às indústrias, pois estas normalmente localizam-se nos eixos destas vias, devendo, nos próximos anos, ser intensificada, particularmente nos Estados atendidos pelo traçado do Gasoduto Bolívia-Brasil, onde as companhias distribuidoras de gás deverão implantar as suas redes de distribuiçăo, que constituirão a infra-estrutura, necessária à prestaçāo dos serviços.

Pergunta-se:

1. Diante das insistentes tentativas do Departamento Nacional de Estradas de Rodagem - DNER, dos Departamentos Estaduais de Estradas de Rodagem (DERs) de alguns Estados, bem como de empresas privadas que adquiriram a concessão de exploração de rodovias, em proceder a cobrança das empresas concessionárias de serviços pelo uso de suas faixas de domínio, é de se indagar da legali- 
dade desta cobrança no uso dessas faixas de domínio de rodovias, sejam elas federais, estaduais ou municipais. Igual questionamento é válido para o caso de ferrovias.

2. Em havendo legalidade na aludida cobrança, é possível a delegação de competência por parte dos órgãos de governo (DNER e/ou DERs) às concessionárias de exploraçāo das rodovias/ferrovias? Qual o critério para determinação do valor, a que título seria e qual a periodicidade?

3. Em havendo a empresa concessionária de distribuição de gás canalizado obtido junto aos órgãos competentes a autorização para a construção de gasodutos e redes em faixas de domínio de rodovias ou ferrovias, pode a concessionária que explora a rodovia/ferrovia, por força do contrato firmado entre esta e o órgão cedente, impedir o início das obras?

4. Levando-se em consideração que as concessionárias de distribuição de gás canalizado usam o subsolo para assentamento de suas tubulações nas faixas de domínio de rodovias/ferrovias e diante de clara diferença entre solo e subsolo, se devida a cobrança, de quem seria a competência: DNER ou Ministério de Minas e Energia?

5. Pode o município, no âmbito de sua competência constitucional, cobrar remuneração, a qualquer título, pela instalação de redes de gás canalizado ou passagem de dutos no seu perímetro urbano?"
PARECER

\author{
Nota propedêutica sobre a \\ interpretação/aplicação do direito
}

01. - O encaminhamento das soluções a serem conferidas aos quesitos propostos na consulta reclama a introdução de breve exposição propedêutica, atinente à interpretação/aplicação do direito.

Essas soluçōes não se encontram previamente dispostas, no interior dos textos normativos, a fim de que lá possam ser descobertas. Ao contrário, devem ser construídas pelo intérprete, à partir dos textos normativos, tal como o farei no desenrolar deste parecer.

Interpretar não é apenas compreender'. A interpretação consubstancia uma operaçāo de mediação que opera a transformação de uma expressão em outra, visando tornar mais compreensível o objeto ao qual a linguagem se aplica $^{2}$

Observei, em meu La doppia destrutturazione del diritto ${ }^{3}$, ser ela um processo intelectivo através do qual, partindo de fórmulas lingüísticas contidas nos textos, inuncidos, preceitos, disposiçòes, alcançamos a determi. naçāo de um conteúdo normativo; mais, observei ser ela atividade voltada ao discern-

1 Vide meus La doppia destrutturazione del diritto (una teoria brasiliana sull'interpretazione), Edizioni Unicopli, Milano, 1996, págs. 55 e ss., La doble desestructuración y la interpretaqción del derecho, trad. de Barbara Rosenberg, M.J. Bosch, Barcelona, 1998, págs. 65 e ss. e $O$ direito posto e $o$ direito pressuposto, cit., págs. 153 e ss.

2 Por isso dizemos que a interpretação do direito é, em um primeiro momento, interpretação semântica, voltada à determinação do significado das palavras e expressōes contidas nos textos normativos. Isto é: refere-se a "normas reveladas por enunciados lingüísticos" (cf. JOSÉ JOAQUIM GOMES CANOTILHO, Direito Constitucional, 4ä, edição, Almedina, Coimbra. 1987, pág. 148), não a intençōes ou vontades do texto ou do legislador.

3 Ob. cit., pág. 59. Esta parte da exposição que produzi neste livro, editado na Itália e, após, na Espanha, não foi publicada em português; é o seguinte o texto italiano: " $L$ 'interpretazione dunque è um processo intellettivo tramite il quale, partendo da formule linguistiche contenute nei testi, enunciati, precetti, disposizjoni, si stabilisce un conenuto normativo. Questa attività interpretativa è volta al discernimento degli enunciati semantici veicolati dai precetti (enunciati, disposizioni, testi). (...) Interpretare è attribuire un significato a uno o più simboli linguistici scritti in un enunciato normativo". Na edição espanhola, cit.. pág. 68. 
imento de enunciados semânticos veiculados por preceitos cenunciados, disposiģoes. textos_. Interpretar - completei - é atribuir um significado a um ou mais simbolos linguísticos escritos em um enunciado normativo!

02. Importa ademais observarmos que interpretar o direito é concretar a lei em cada caso, ou seja, é aplicar a lei; o intérprete, ao interpretar a lei, desde um caso concreto, a aplica. Daí dizermos que interpretação e aplicação não se realizam, autonomamente. $O$ intérprete discerne o sentido do texto a partir e em virtude de um determinado caso dado ${ }^{3}$. Assim, existe uma equação entre interpretação e aplicação: não estamos, aqui, diante de dois momentos distintos, porém frente a uma só operaçāo ${ }^{4}$. Interpretação e aplicação se superpōem.

Ora, sendo, a interpretação, concomitante- mente aplicação do direito. deve ser entendida como produção prática do direito. precisamente como a toma FRIEDRICH MÜL$\mathrm{LER}^{5}$, para quem inexiste tensão entre direito e realidade; não existe um terreno composto de elementos normativos, de um lado. e de elementos reais ou empíricos, do outro. Por isso a articulação ser e dever-ser [a relação norma-fatol é mais do que uma questāo da filosofia do direito; é uma questão da estrutura da norma jurídica tomada na sua transposição prática e, por consequiência, ao mesmo tempo uma questão da estrutura deste processo de transposição.

Isso significa que a norma é produzida, pelo intérprete, não apenas a partir de elementos que se despreendem do texto [mundo do dever-ser], mas também a partir de elementos do caso [ = dos fatos $]$ ao qual será ela aplicada,

I Daí a necessidade de considerarmos a distinção entre texto e norma. O texto, preceito, enunciado normativo é alográfico (vide meu La doppia destrutturazione del diritto - Una teoria brasiliana sull 'interpretazione, cit., págs. 57 e ss.: tb. La doble desestructuración y la interpretación del derecho. cit., págs. 67 e ss.). Não se completa no sentido nele impresso pelo legislador. A "completude" do texto somente é realizada quando o sentido por ele expressado é produzido, como nova forma de expressão. pelo intérprete. Mas o "sentido expressado pelo texto" já é algo novo, distinto do texto. É a norma. Temos assim bem clara a distinção entre o texto (enunciado, disposição) e a norma (a respeito da distinção entre texto e norma. vide RICARDO GUASTINI. interprétation et description de normes, in Interprétation et Droit. publié sous la direction de Paulo Amselek. Bruylant. Bruxelles, 1995. pág. 325 e Le fonti del diritto e l'interpretazione. Giuffrè. Milano. 1993, pág. 18: tb. NEIL MacCORMICK. La texture ouverte des règles juridiques. in Controverses autour de l'ontologie du droit. publié sous la direction de Paul Amselek et de Christophe Grzegorczyk. Presses Universitaires de France, Paris. 1989, págs. 93-96). Um e outra (texto e norma) nāo se identificam: o texto é o sinal lingüistico: a norma é o que se revela, designa (cf. JOSÉ JOAQUIM GOMES CANOTILHO - Direito Constitucional, $5^{3}$ edição. Almedina, Coimbra. 1.991. pág. 225). Daí também dizermos ser, a interpretą̧ão, uma atividade que se presta a transformar disposiçōes (textos, enunciados) em normas. A compreensão disso permite ao intérprete observar que nem sempre um e outra - o texto normativo e a norma - correspondem (veja-se o CANOTILHO, ob. cit., $5^{\mathfrak{a}}$ edição. págs. 211 e ss.), seja porque determinada norma pode ser produto da interpretação conjunta de mais de um texto normativo, seja porque um mesmo texto normativo pode ser moldura para a produção de mais de uma norma (vide meu La doppia destrutturazione del diritto - Una teoria brasiliana sull'interpretazione. cit., pág. 61); tb. La doble desestructuración y la interpretación del derecho. cit.. pág. 71).

2 Cf. HANS-GEORG GADAMER - Vedad y metodo. cuarta edición. trad. de Ana Agud Aparicio y Rafael de Agapito. Ediciones Sigueme. Salamanca. 1.991. pág. 401.

3 Idem. pág. 397.

4 Vide ENRIQUE E. MARÍ - La imterpresacion de la ley: Análisis histórico de la escuela exegética y su nexo con el processo codificatorio de la modernidad, in "Materiales para una teoria crítia del derecho". Enrique E. Marí el alii. Abeledo-Perrot. Buenos Aires, 1991, pág. 236.

5 Juristische Methodik, $5^{a}$ edição. Duncker \& Humblot. Berlin. 1993, págs. 145-146. 
isto é. a partir de elementos da realidade [mundo do ser]'.

$O$ que incisivamente deve aqui ser afirmado, a partir da metáfora de KELSEN² ${ }^{2}$ é o fato de a "moldura da norma" ser, diversamente, moldura do texto, mas não apenas dele; ela é, concomitantemente, moldura do texto e moldura dos fatos. O intérprete interpreta também os fatos, necessariamente, além dos textos, ao empreender a produçāo prática do direito.

Isso reclama do intérprete a efetiva consideração, em cada caso, não apenas dos textos [de todo o direito, à partir da Constituiçāo], mas também dos fatos, até porque desse enlace é que resulta [a produção da] a norma. A interpretação de ambos, textos e fatos, dá lugar à norma [= decisão] aplicável ao caso.

Por isso o trabalho jurídico de construção da norma aplicável a cada caso é trabalho artesanal. Cada solução jurídica, para cada caso, será sempre, renovadamente, uma nova solução. Por isso mesmo - e tal deve ser enfatizado - a interpretação do direito se realiza não como mero exercício de leitura de textos normativos, para o que bastaria ao intérprete ser alfabetizado.

Essas verificações me permitem tratar de modo mais fluente das questōes que me foram propostas, na construção das soluções jurídicas a elas aplicáveis.
Serviço público, desapropriação e servidão

03. - As empresas referidas na consulta, que a consulente congrega e representa, são prestadoras de serviço público de distribuição de gás canalizado em vários Estados da Federaçāo [\$ $2^{2}$ do art. 25 da Constituição do Brasil].

O controle acionário de algumas delas foi transferido ao setor privado - estas são autênticas concessionárias daquele serviço público; as demais permanecem sendo empresas estatais estaduais, delegadas do Estado-membro para a prestação do serviço público ${ }^{3}$.

O que importa, contudo, é a circunstância de a toda elas incumbir o dever-poder ${ }^{4}$ de prestar o serviço público de que se trata.

04. Para tanto - ou seja, a fim de que essas empresas possam desincumbir-se do deverpoder que as vincula - a elas é atribuído. pelos Estados-membros, o também dever-poder de usar o domínio público necessário à execução do serviço, bem como de promover desapropriações e constituir servidōes de áreas declaradas de utilidade pública por ele, poder concedente [o Estado-membro].

Com pequenas variaçōes redacionais, neste sentido dispōem os assim designados "contratos de concessão" celebrados pelas delegadas/concessionárias do serviço e cada Estado-

1 Vide CRISTIANE DERANI, Direito Ambiental Econômico, Max Limonad, São Paulo, 1997, págs. 40-44.

2 Teoria pura do direito, trad. de Joāo Baptista Machado, $4^{\mathrm{a}}$ edição, Armênio Amado Editor, Coimbra, 1979, pág. 467.

3 Para a distinção entre concessionária de serviço público e empresas estatais delegadas para a execução do serviço público, vide meu A ordem econômica na Constituiçāo de 1988, $4^{\mathrm{a}}$ edição, Malheiros Editores, São Paulo, 1998, págs. 151 e ss.

4 Deve-se a introduçāo de ênfase ao dever, na afirmaçāo da funçāo como poder-dever, a CELSO ANTÔNIO BANDEIRA DE MELLO. A referência a dever-poder nāo é expressiva de alteração meramente formal no ermo do conceito, porém de efetiva reformulação do conceito. A ênfase posta por CELSO ANTÔNIO no vocábulo dever evidencia que a função autoriza o seu titular a exercer determinados poderes. ao contrário do que anteriormente seria possível supormos. ou seja, que o poder detido pelo titular da funçāo teria de ser exercido por consubstanciar um dever. À propósito, vide meu Licitação e contrato administrativo, Malheiros Editores, São Paulo, 1.995, págs. 40-41. A Administração desempenha função: pode fazer tudo quanto deva fazer, nada mais.

5 Referindo as pessoas concessionárias de serviço público, diz SEABRA FAGUNDES (Da desapropriação no direito brasileiro, Livraria Editora Freitas Bastos, Rio de Janeiro. 1.942, pág. 69): “a permissão dada a tais pessoas para promover a desapropriaçāo não constitue mais do que uma extensão natural de atribuição de executar o serviço público concedido". 
membro. Outrossim, a lei federal $n^{2} 8.897$. de 13 de fevereiro de 1995 , define incumbir à concessionária do serviço promover as desapropriaçōes e constituir servidões autorizadas pelo poder concedente, conforme previsto no edital e no contrato (art. 31, VI).

05. - As servidões que podem ser constituídas por essas empresas são administrativas ou públicas, distintas, pois, das servidões $c i$ vis'.

A desapropriação, ensina SÉRGIO DE ANDRÉA FERREIRA ${ }^{2}$, em sentido amplo, tal como constitucionalmente tomada, abrange tanto a forma extintiva do domínio e de outros direitos patrimoniais sobre um determinado bem, quanto a forma restritiva dos mesmos. Em determinados casos será desnecessária a apropriação do bem pelo Estado, o que conduziria à extinção de direitos. Bastará, na hipótese, a imposição de uma restrição ao exercício do direito sobre o bem; criar-se-á, entāo um direito restritivo em favor do beneficiário, que poderá ser um direito real limitado ou um direito pessoal patrimonial.

Nesta segunda hipótese, afirma ainda SÉRGIO DE ANDRÉA FERREIRA ${ }^{3}$, " ao contrário da extinção, o que há é uma criação, sendo o direito limitativo do Poder Público de natureza potestativa criativa ou geradora, com consequiências restritivas".

A servidão administrativa ou pública consubstancia um direito limitativo do Estado, definindo-se como uma restrição imposta ao particular quanto ao exercício do seu direito de propriedade sobre determinado bem. Daí dizermos que a servidāo administrativa ou pública incide sobre a propriedade privada.

Não conduzindo à extinção de direitos, a constituiçāo de servidões administrativas [ou públicas] não acarreta, em princípio, o dever de indenizar, salvo disposiçāo legal expressa em contrário ${ }^{4}$.

06. - As empresas de que se cuida, concessionárias ou delegadas do Estado-membro para a prestação de serviço público, fazem uso fundamentalmente, a fim de que possam prestá-lo, do sub-solo de faixas de domínio público de rodovias e de vias públicas, no qual implantam dutos de maior ou menor porte, necessários ao transporte e à distribuição de gás canalizado.

Por esse uso é que pretendem, o Departamento Nacional de Estradas de Rodagem DNER, os Departamentos Estaduais de Estradas de Rodagem - DERs e concessionários de rodovias federais e estaduais, bem assim alguns Prefeitos Municipais, ser remunerados, mediante o recebimento de um preço.

Sucede que essas faixas de domínio público de rodovias e de vias públicas constituem bem público, inseridos na categoria dos bens de uso comum do povo; de mais a mais, do subsolo dessas faixas de domínio público é que aquelas empresas fazem uso.

\section{Bens públicos e seu uso}

07. - O Código Civil, em seu artigo 65, classifica os bens em públicos e particulares, definindo que sāo públicos os do domínio nacional, pertencentes à União, aos Estados ou aos Municípios. Todos os demais, seja qual for a pessoa a que pertencerem, são entendidos como particulares.

Os bens públicos, pertencentes à Uniāo, aos Estados ou aos Municípios, assim os classifica o Código, em seu artigo 66:

"I - Os de uso comum do povo, tais como os mares, rios, estradas, ruas e praças.

II - os de uso especial, tais como os

I Vide, por todos, SÉRGIO DE ANDRÉA FERREIRA, $O$ direito de propriedade $e$ as limitaçöes $e$ ingerências administrativas. Editora Revista dos Tribunais. São Paulo, 1980, págs. 70-71.

2 Ob. cit., pág. 64).

3 Ob. e loc. cits.

4 Neste sentido, SÉRGIO DE ANDRÉA FERREIRA, ob. cit., págs. 66-67 e 72. 
edifícios ou terrenos aplicados a serviço ou estabelecimento federal, estadual ou municipal.

III - Os dominicais, isto é, os que constituem o patrimônio da União, dos Estados, ou dos Municípios, como objeto de direito pessoal ou real de cada uma dessas entidades".

Os bens públicos, de uso comum do povo, de uso especial e dominicais, integram, todos eles, o patrimônio público, mas os bens de uso comum do povo são modemamente entendidos como propriedade pública.

Tamanha, no entanto, é a intensidade da participação do bem de uso comum do povo na atividade administrativa que ele constitui, em si, o próprio serviço público (objeto de atividade administrativa) prestado pela Administração'.

Entende-se por uso comum, de outra parte — este é o ensinamento de FORSTHOFF ${ }^{2}$ o uso de um bem que, sem autorizaçāo especial, é acessível a todos ou a pelo menos a um conjunto nāo individualizado de pessoas.

08. - Isso poderia inicialmente nos levar a afirmar ser descabida a pretendida cobrança de remuneração pelo uso desses bens, de uso comum do povo.

Contra tanto será porém dito que as empresas referidas na consulta, prestadoras do serviço público de distribuição de gás canalizado, fazem uso especial - e nāo uso comum - dos bens de uso comum, já que deles não se valem para exercer o direito à circulação, "que é a manifestação mais característica do direito de locomoção, direito de ir e vir e também de ficar (estacionar, parar) assegurado pela Constituição Federal" 3 , mas sim para, em seu sub-solo, instalar redes de gás canalizado ou passar dutos de maior ou menor porte, necessários ao transporte e à distribuição de gás canalizado. Por isso - dir-se-á - justificar-se-ia a cobrança de um preço por tal uso.

Aqui, mais uma vez, caberia vigorosa contradita, esgrimida desde a afirmação de que as empresas de que se cuida poderiam, se propriedade particular fossem as áreas correspondentes a esses bens de uso comum do povo, obter declaração de utilidade pública de seu sub-solo pelos Estados-membros, a fim de constituirem servidōes administrativas suficientes para permitirem aquele uso especial independentemente do pagamento de qualquer remuneração.

09. - Logo se vê que duas circunstâncias conferem complexidade à hipótese:

[i] a primeira delas repousa sobre o fato de os bens a serem utilizados pelas empresas prestadoras de serviço público não constituírem propriedade privada, mas sim bens de uso comum do povo; pois é certo, bem certo, que se de propriedade particular se tratasse as empresas delegadas/concessionárias do serviço público poderiam constituir servidōes administrativas, que - repito - não conduzindo à extinção de direitos, não acarretariam, em princípio, o dever de indenizar, salvo disposiçāo legal expressa em contrário, no caso inexistente;

[ii] a segunda, sobre o fato de o uso feito pelas empresas prestadoras de serviço público consubstanciar uso especial, e não uso comum de bens de uso comum.

Sendo assim, não é razoável que as empresas de que se trata sejam oneradas mercê precisamente da peculiaridade de serem prestadoras de serviço público.

10. - Explico-me.

Os bens de uso comum do povo consubstanciam propriedade pública. Não consubstanciam bens de propriedade do Estado; são,

1 Neste sentido. RUY CIRNE LIMA, Princípios de Direito Administrativo, $5^{\text {a }}$ edição, Editora Revista dos Tribunais, São Paulo. 1982, pág. 77.

2 Lehrbuch des Verw'altungsrecht, 1, 10. Auflage, C.H. Beck'sche Verlagsbuchhandlung, München, pág. 390.

3 Cf. JOSÉ AFONSO DA SILVA, Direito urbanistico brasileiro, Editora Revista dos Tribunais, São Paulo, 1981, págs. 226-227. 
como ensina RUY CIRN LIMA' ' qual os bens do patrimônio administrativo, "insusceptíveis de propriedade, quer dizer, de vincular-se. pelo laço do direito real, a uma vontade ou personalidade".

De outra banda, como vimos, constituem, em si, o próprio serviço público (objeto de atividade administrativa) prestado pela Administração. Mas assim é apenas enquanto os particulares deles façam o uso comum [= uso normal]

Quando porém deles faça uso nāo um particular, mas o próprio Estado ou entidade prestadora de serviço público, e para fim de prestação desse serviço, tais bens já não constituem o próprio serviço, mas innstrumentam a prestação de outro serviço público.

Logo, porque não pode ser tratado como propriedade pública o bem público de uso comum que não constitui serviço público ou seja, que não realiza sua finalidade - mas instrumenta a prestação de outro serviço público, seria perfeitamente possível, desde que isso não comprometesse o uso comum do bem de uso comum, constituir-se um direito restritivo sobre esse bem.

11. O fato é que, ainda que os bens do domínio público e do patrimônio administrativo não tolerem o gravame das servidões ${ }^{2}$, sujeitam-se, no caso de que tratamos, aos efeitos da restrição decorrente da passagem, pelo seu sub-solo, de dutos de maior ou menor porte, necessários ao transporte e à distribuição de gás canalizado.

Por certo que não conduzindo, a imposição dessa restrição, à extinção de direitos, não acarreta o dever de indenizar, salvo disposição legal expressa em contrário, no caso contudo inexistente.

Por fim, além de a passagem de dutos de que se trata não comprometer o uso comum dos bens públicos em questão, é também certa, no caso, a inexistência de prejuízo que justifique o recebimento, pelo Estado, de qualquer indenização pelo uso do sub-solo do bem público de uso comum.

Lembro, à propósito, o preceito veiculado pelo $\S 1^{\Omega}$ do artigo $2^{\circ}$ do Decreto-lei $n^{\circ} 3.365$, de 21 de junho de 1941: "A desapropriaçāo do espaço aéreo ou do sub-solo só se tornará necessária quando de sua utilização resultar prejuizo patrimonial do proprietário do solo". Vem a calhar, aqui, a observação de SEABRA FAGUNDES": "Portanto; a desapropriação só tem lograr, em se tratando de sub-solo e do espaço atmosférico, excepcionalmente. É preciso que o uso desses elementos realmente prejudique a utilização do imóvel correspondente para que se torne necessário o expropriamento".

12. - Assim se resolve a principal questão versada na consulta: há, na ocupação do subsolo dos bens de uso comum de que se cuida, um direito restritivo em benefício do prestador de serviço público, direito restritivo este que a ele possibilita, instrumentando sua atuaçāo, o pleno cumprimento do dever-poder, que o vincula, de prestar o serviço.

A conclusāo de que não cabe a percepção, pelo Município, pelo Estado-membro e pela União, de qualquer preço por essa ocupação far-se-á prontamente mansa e pacífica, após a breve exposição que segue.

\section{Preço e relação de intercâmbio}

13. - Preço ${ }^{4}$ é conceituado, na linguagem corrente, como o quantum exigido, geralmente em dinheiro, para a aquisição de determinada mercadoria, coisa ou serviço ${ }^{5}$

1 Ob. cit., pág. 75.

2 Vide RUY CIRNE LIMA, ob. cit., pág. 195.

3 Ob. cit., pág. 56.

4 Vide meu Licitação e contrato administrativo, Malheiros Editores, São Paulo, 1995, págs. 90 e ss.

5 Sucede, contudo, que o direito positivo expressa através de distintos vocábulos diversas retribuições pela aquisiçāo de mercadorias, coisas e serviços. Assim. o Código Civil refere: aluguel (artigo 1.192. II), salário (parágrafo único do artigo 1.221). juros (artigos 1.263 e 1.303), remuneraçāo (artigo 1.310), prêmio (artigo 1.432), indenização (parágrafo único do artigo 1.338). 
O conceito de preço envolve tanto a noção de dinheiro - pretium in numerata pecunia consistere debet ${ }^{\prime}$ - quanto a de contraprestação. O preço é uma prestação, consistente em dinheiro, que corresponde a uma contraprestação de outra natureza ${ }^{2}$. Na medida em que prestaçāo por contraprestação, é expressão de uma equivalência em termos patrimoniais.

O preço, dessarte, é elemento dos contratos de intercâmbio, aos quais von IHERING alude como Verträge des Tauschverkehrs ${ }^{3}$ e nos quais se reclama uma equivalência entre prestação e contraprestação. Entenda-se aí equivalência, segundo ainda von IHERING, como a justa proporção entre prestação e contraprestaçāo ${ }^{4}$, o equilíbrio entre ambas, inferido através da experiência, desde o qual os contratantes entram em acordo'.

Preço, pois, é a contrapartida com a qual, nos contratos de intercâmbio ${ }^{h}$, uma parte comparece perante outra parte em uma situação de diversidade de necessidades recíprocas, que, por isso mesmo, são satisfeitas mediante a troca de prestaçōes diversas.

14. - Ora, no caso de que cogitamos nāo há relação de intercâmbio entre as empresas concessionárias ou delegadas do Estadomembro para a prestação de serviço público de distribuiçāo de gás canalizado, de um lado, e, de outro, as autarquias, concessionárias e Municípios que pretendem receber preço mercê da utilizaçāo, pelas primeiras, para o fim de prestarem serviço público, do sub-solo de bens públicos de uso comum por elas, estas últimas, administrados.

É inadmissível suportar-se a cobrança de preço sobre direito restritivo que confere ao prestador de serviço público a faculdade de passar, pelo sub-solo de bens de uso comum, dutos de maior ou menor porte, necessários, no caso, ao transporte e à distribuição de gás

\section{Inst., III, 23, 2.}

2 Cf. ARTHUR NUSSBAUM, Teoria juridica del dinero, trad. de Luis Sancho Seral, Librerie General de Victoriano Suáres, Madrid, 1929, pág. 26.

3 Der Zweck im Recht, Erster Band, Zweite Umgearbeite Auflage, Druck und Verlag von Breitkopf \& Härtel, Leipzig, 1.884, pág. 129.

4 Ob. cit., pág. 132.

5 Ob. cit., pág. 133.

6 Para a distinção entre estes e os contratos de comunhāo de escopo, veja-se von IHERING, em seu monumental Der Zweck im Recht, ob. cit., págs. 212/213. Nos contratos de intercâmbio cada parte persegue os seus próprios interesses; quanto mais desvantajosa for a compra para o comprador, mais vantajosa será para o vendedor, e vice-versa; a política de cada parte pode ser sumariada na seguinte frase: o prejuízo dele é o meu lucro (sein Schaden mein Gewinn). Nos contratos de comunhão de escopo - von IHERING refere-se aos contratos de sociedade - os interesses dos contratantes são paralelos. Se um dos contratantes sofre prejuízo, os outros também o suportam. Do espírito de solidariedade de interesses que os caracteriza, o lema: a vantagem dele é a minha vantagem, minha vantagem é a sua vantagem (sein Vorteil mein Vorteil, mein Vorteil sein Vorteil). A distinção, em verdade, fora já discernida por GRÓCIO. no século XVII, como observa ASCARELLI (Problemas das Sociedades Anônimas e Direito Comparado, $2^{2}$ ed., Saraiva, São Paulo, 1969, pág. 255): os contratos de intercâmbio dirimunt partes, os de comunhão de escopo communionem adferunt. Se nos contratos de intercâmbio o elemento fundamental é o sinalagma - vínculo de recíproca dependência entre as obrigações do contrato bilateral - na associação. como na sociedade e no consórcio. o elemento fundamental é o escoopo (objetivo) comum (vide FÁBIO KONDER COMPARATO, Ensaios e Pareceres de Direito Empresarial, Forense, Rio de Janeiro, 1978. pág. 137 e Novos Ensaios e Pareceres de Direito Empresarial, Forense. Rio de Janeiro, 1981. pág. 44). Daí a observação, ainda de von IHERING (ob. cit., pág. 208): o contrato de intercâmbio tem por pressuposto a diversidade, enquanto que o contrato de sociedade - contrato de comunhảo de escopo - a identidade de objetivo. 
canalizado. Ademais, ainda que essa restrição fosse indenizável, ao seu beneficiário [dela, restrição indenizável] seria atribuído o dever de pagar indenizaçāo - nāo se trataria, na hipótese, de obrigação de pagamento de precol.

E assim é porque não existe, no caso, contraprestação - mercadoria, coisa ou serviço - que justifique o pagamento de preço.

Desejo deixar este ponto bem vincado: às empresas concessionárias ou delegadas do Estado-membro para a prestação de serviço público de distribuição de gás canalizado é atribuído pelo ordenamento jurídico o dever-poder de utilização, como instrumental da prestação daquele serviço público, do sub-solo dos bens públicos de uso comum administrados pelas autarquias, concessionárias e Municípios de que se trata.

Para logo se vê, destarte, ser juridicamente incabível a cobrança de qualquer preço por aquela utilizaçāo. Essa conclusāo deve, no entanto, ser ponderada à luz do critério do interesse público e, após, da Constituição do Brasil.
O interesse puiblico

15. - Os interesses públicos, coletivos, cuja satisfaçāo deve ser perseguida pela Administração, não são, qual ensina RENATO ALESSI $^{2}$, simplesmente o interesse da Administração enquanto aparato organizacional autônomo, porém aquele que é chamado interesse coletivo primário. Este é resultante do complexo dos interesses individuais prevalentes em determinada organização jurídica da coletividade, ao passo que o interesse do aparato organizacional que é a Administraçào, se pode ser concebido um interesse, desse aparato, unitariamente considerado, será simplesmente um dos interesses secundários que se fazem sentir no seio da coletividade é que podem ser realizados somente na medida em que coincidam, e nos limites dessa coincidência, com o interesse coletivo primário.

A distinção - fundamental e necessária entre interesse público primário e interesse da Administração (interesse público secundário) também está pacificada entre nós ${ }^{3}$.

1 Para a distinção entre dever e obrigação, vide meu Direito, conceitos e normas jurídicas, Editora Revista dos Tribunais, São Paulo, 1988, págs. 114 e ss.

2 Principi di Diritto Amministrativo, I, quarta edizione, Giuffrè. Milano, 1978, págs. 232/233: “Questi interessi pubblici. colletrivi, dei quali l'amministrazione deve curare il soddisfacimento, non sono, si noti bene, semplicemente l'interesse dell'Amministrazione intesa come apparato organizzativo autonomo. sibbene quello che è stato chiamato l'interesse colletrivo primario, formato dal complesso degli interessi individuali prevalenti in una determinata organizazione giuridica della collettività, mentre l'interesse dell'aparato, se può esser concepito un interesse dell'apparato unitariamente considerato, sarebbbe semplicemente uno degli interessi secondari che si fanno sentire in seno alla collettività, e che possono essere realizzati soltanto in caso di coincidenza, e nei limiti di siffatta coincidenza, con l'interesse collettivo primario. La peculiarità della posizione giuridica della pubblica Amministrazione sta appunto in ciò, che la sua funzione consiste nella realizzazione dell ineresse collettivo, pubblico, primario. Anche volendosi concepire un interesse, secondario, dell Amministrazione considerata comme apparato organizzativo autonomo, esso non potrebbe esser realizzato se non in vista della coincidenza con l'interesse primario, pubblico". CARNELUTTI distingue ineresses que são individuais na modalidade e coletivos na finalidde, chamando-os interesses coletivos mediatos ou secundários (Sistema di Diritto Processuale Civile, I, CEDAM, Padova. 1936. págs. 11/12).

3 Diz CELSO ANTÔNIO BANDEIRA DE MELLO (Curso de Direito Administrativo, 4a edição. Malheiros Editores. São Paulo, 1993, pág. 22). após averbar que os interesses públicos ou interesses primários sāo os interesses da coletividade como um todo e os interesses secundários são os que o Estado (pelo só fato de ser sujeito de direitos) poderia ter como qualquer outra pessoa, isto é. independentemente de sua qualidade de servidor de interesses da coletividade: "Poderia, portanto lo Estado, a Administra(̧ão), ter o interesse secundário de resistir ao pagamento de indenizaçōes, ainda que procedentes, ou de 
Por certo é possível tomarmos como interesse da Administraçāo o de pagar o mínimo a seus credores, com o que ela, Administração, permaneceria "mais rica". Mas esses interesses - interesses públicos secundários - diz ALESSI, “ possono essere realizati soltanto in caso di coincidenza, e nei limiti di siffatta coincidenza, con l'interesse collettivo primario" - interesse como tal "non potrebbe esser realizzato se non in vista della coincidenza con l'interesse primario, pubblico"; ou na dicçāo de CELSO ANTÔNIO BANDEIRA DE MELLO', esses interesses "não são atendiveis senão quando coincidirem com interesses primários, únicos que podem ser perseguidos por quem axiomaticamente os encarna e representa."

16. - A cobrança pretendida pelo Departamento Nacional de Estradas de Rodagem DNER, pelos Departamentos Estaduais de Estradas de Rodagem - DERs e por concessionárias de rodovias federais e estaduais, bem assim por alguns Municípios, teria o condão de deixar mais rica a Administração - salvo no caso das concessionárias de rodovias, quando o enriquecimento beneficiaria o particular [ = a concessionária $]$ - mas não prestaria absolutamente nenhuma satisfação ao interesse público.

Deveras, este será beneficiado na medida em que os serviços públicos, genericamente, sejam prestados, de modo adequado, pelo menor custo possível.

Inexistindo porém, no caso, contraprestação que justifique o pagamento do preço que se pretende cobrar, essa cobrança, onerando indevidamente aquele custo, por certo não beneficiará o interesse público.

Daí porque a ponderação da conclusão acima enunciada à luz do critério do interesse público presta-se a reafirmá-la: a cobrança, às empresas concessionárias ou delegadas do Estado-membro para a prestação de serviço público de distribuição de gás canalizado, de qualquer preço pelo uso do subsolo dos bens públicos de uso comum administrados pelas autarquias, concessionárias e Municípios de que se trata afronta o interesse público pri-

denegar pretensōes bem fundadas que os administrados lhe fizessem, ou de cobrar tributos ou tarifas por valores exagerados. Estaria, por tal modo, defendendo interesses apenas 'seus', enquanto pessoa, enquanto entidade animada do propósito de despender o mínimo de recursos e abarrotar-se deles ao máximo. Nāo estaria, entretanto, atendendo ao interesse público, ao interesse primário, isto é, àquele que a lei aponta como sendo o interesse da coletividade: o da observância da ordem jurídica estabelecida a título de bem curar o interesse de todos. Por isso os interesses secundários não são atendíveis senão quando coincidirem com interesses primários, únicos que podem ser perseguidos por quem axiomaticamente os encarna $e$ representa. Percebe-se, pois, que a Administraçāo não pode proceder com a mesma desenvoltura e liberdade com que agem os particulares, ocupados na defesa das próprias conveniências, sob pena de trair sua missão própria e sua própria razão de existir". É insiste ainda, o mesmo autor (pág. 46): "Interesse público ou primário é o pertinente à sociedade como um todo e só ele pode ser validamente objetivado, pois este é o interesse que a lei consagra e entrega à compita do Estado como representante do corpo social. Interesse secundário é aquele que atina tão-só ao aparelho estatal enquanto entidade personalizada e que por isso mesmo pode lhe ser referido e nele encarnar-se pelo simples fato de ser pessoa. Para exemplificar o importante discrímen entre um e outro, comparem-se as seguintes hipóteses. Se o Estado causar danos a terceiros e indenizá-los das lesões inflingidas estará revelando-se obsequioso ao interesse público, pois é isto o que determina o art. 37, parágrafo $6^{\circ}$, da Constituiçẫo. Se tentar evadir-se a este dever de indenizar (mesmo consciente de haver produzido os danos) estará contrariando o interesse público, no afã de buscar um interesse secundário, concernente apenas ao aparelho estatal: interesse em subtrair-se a despesas (conquanto devidas) para permanecer 'mais rico', menos onerado patrimonialmente, lançando, dessarte, sobre ombros alheios os ônus que o Direito pretende sejam suportados por todos. Tal conduta não é de interesse público, pois interesses secundários só podem ser satisfeitos quando coincidirem com interesses primários".

1 Ob. cit., pág. 22. 
mário, ainda que possa dar satisfação ao interesse da Administraçāo, interesse secundário.

Serviço público na Constituição do Brasil e a falsa "privatização de serviço público"

17. - Cumpre por fim ponderarmos a conclusāo alcançada à luz da Constituição do Brasil, indagando da sua compatibilidade aos princípios desta.

Relembre-se antes de tudo, aqui, que, assim como se dá com o direito, não se interpreta a Constituiçāo em tiras, aos pedaços. A interpretação de qualquer texto normativo da Constituição impōe ao intérprete, sempre, em qualquer circunstância, o caminhar pelo percurso que se projeta a partir desse teto até a Constituição em sua totalidade normativa!. Um texto normativo isolado, destacado do sistema jurídico, nada significa e pode tudo significar, segundo a aptidão retórica de quem o maneje.

Ora, a Constituição brasileira de 1988 não se limita a ser a Constituição do Estado brasileiro; ela é a Constituição da sociedade brasileira, definindo um programa para a socie- dade brasileira: ela é a Constituiçāo do Brasil. Por isso, quem a compreenda como ela deve ser compreendida [isto é, em seu todo, enquanto totalidade normativa] nela divisa preceitos que afirmam a coexistência, em nossa ordem econômica, de distintas áreas - área do serviço público (art. 175) e área da atividade econômica (art. 173) ${ }^{2}$ - cuja preservaçāo é essencial à realização dos princípios afirmados em seus artigos $1^{2}, 3^{2}$ e 170 , para referirmos o mínimo ${ }^{3}$.

Por isso se pode e deve afirmar que a privatização de empresas estatais é compatível com a Constituição do Brasil, mas a privatização dos serviços públicos é com ela inteiramente incompatível ${ }^{4}$, visto comprometer aquela preservação.

Haverá serviço público, entre nós, no regime da Constituição de 1988 - digo-o glosando o magistral conceito de RUY CIRNE LIMA $^{5}$ - sempre que determinada atividade seja, em face e em decorrência da concretização daqueles princípios, tida como existencial, relativamente à sociedade, por isso mesmo tendo de ser prestada aos componentes daquela, direta ou indiretamente, pelo Estado ou outra pessoa administrativa.

Daí porque o serviço público constitui cam-

1 Vide meus $A$ ordem econômica na Constituição de 1988, cit., págs. 176-177; La doppia destrutturazione del diritto, cit., pág. 80: e La doble desestructuración y la interpretación del derecho, cit., pág. 91.

2 atividade econômica em sentido estrito; vide meu $A$ ordem econômica na Constituição de 1988, cit., págs. 129 e ss.

3 O artigo $1^{2}$ da Constituição do Brasil afirma-o como Estado Democrático de Direito, enunciando seus fundamentos: I - a soberania; II - a cidadania; III - a dignidade da pessoa humana; IV - os valores sociais do trabalho e da livre iniciativa: $V$ - o pluralismo político; o artigo $3^{2}$ define os objetivos fundamentais do Brasil: I - construir uma sociedade livre, justa e solidária; II - garantir o desenvolvimento nacional; III - erradicar a pobreza e a marginalizarāo e reduzir as desigualdades sociais e regionais; IV - promover o bem de todos, sem preconceitos de origem, raça, sexo, cor, jdade e quaisquer outras formas de discriminação; e, no artigo 170, a Constituição do Brasil diz que "A ordem econômica, fundada na valorização do trabalho humano e na livre iniciativa, tem por fim assegurar a todos existência digna, conforme os ditames da justiça social, observados os seguintes princípios: I - soberania nacional: II - propriedade privada; III - função social da propriedade; IV - livre concorrência; V - defesa do consumidor; VI - defesa do meio ambiente; VII - redução das desigualdades regionais e sociais; VIII - busca do pleno emprego; IX - tratamento favorecido para as empresas pequeno porte constituídas sob as leis brasileiras e que tenham sede e administração no País".

4 Toda a gente sabe que à concessão de serviço público não corresponde privatização do serviço, que permanece sob a titularidade do Estado, poder concedente.

5 Ob. cit., pág. 82. 
po de atuação próprio do Estado e não parcela da atividade econômica, esta constitucionalmente atribuída à titularidade do setor privado.

No Brasil, enquanto vigente a Constituição de 1988, não será possível a privatizaçāo dos serviços públicos (art. 175 dela), ainda que repito - possam ser concedidos e/ou permitidos a particulares, sem que isso importe na sua privatização.

18. - Toda essa derradeira exposição se justifica na medida em que permite discernirmos com precisão o fato de a Constituição de 1988 não suportar a cobrança de preço pretendida pelas autarquias, concessionárias e Municípios, contra prestadoras de serviço público. Pois é certo que essa cobrança importaria em uma inadmissível "privatização" dos direitos restritivos, de passagem, indispensáveis à prestação de serviços públicos pelo Estado [passagem de dutos de maior ou menor porte, necessários ao transporte e à distribuição de gás canalizado, no caso].

19. - Sendo assim, apurada a incompatibilidade da cobrança em pauta com a Constituição do Brasil, cobrança que, ademais, é avessa ao interesse público, estou em condições de tratar das matérias atinentes a cada um dos quesitos propostos na consulta.

\section{Conclusões}

20. - Quanto à pretensão do Departamento Nacional de Estradas de Rodagem - DNER, o preceito contido no artigo 4 , VI do decreto n 512/69 nada justifica, é imprestável. Exploração e arrendamento de bens patrimoniais do seu acervo dariam lugar exclusivamente à cobrança de preço, remuneração típica das relações de intercâmbio, inocorrente no caso de que cogitamos. O mesmo se diga dos contratos de concessão da operação de rodovias.

No que tange à Portaria $n^{2} 410 / 99$, do DNER, nitidamente procura ocultar, mediante alusão a "cobrança de licença à título onero- so", a ausência de fundamento para a cobrança de um preço [remuneração], aos órgãos da Administração e às empresas privadas concessionárias de serviço público, pela utilização das faixas de domínio.

Ora, se de licença se tratasse, expressão do exercício, pelo DNER, de regular poder de polícia, a "remuneraçāo" consubstanciaria taxa, que não poderia ser criada sem lei ${ }^{1}$. Não há no caso, porém, a instituir essa espécie de tributo, nenhuma lei, senão mera portaria e contraditória: o artigo 12 menciona "cobrança de licença a título oneroso", mas o artigo $2^{2}$ refere valores denominados "remuneração". A cobrança é, de qualquer ângulo, insustentável - taxa é tributo, que se não pode cobrar sem lei que o tenha instituído; a cobrança de "remuneração" [= preço] é, no caso, inadmissível.

De outra parte, não vejo como e sob qual fundamento poderia, qualquer concessionária que explore a operação de rodovia ou ferrovia, impedir o início das obras necessárias à prestação do serviço público de distribuiçāo de gás canalizado, em especial quando essas obras tenham sido aprovadas pelos órgãos competentes para autorizar a construção de gasodutos e redes em faixas de domínio de rodovias ou ferrovias.

Devo lembrar, por fim, que o decreto municipal n 38.139/99, do Município de São Paulo, em seu artigo $8^{\circ}$ expressamente chama de "preço" a contribuiçāo pecuniária pela utilização das vias públicas, preço que, como vimos, não se pode, no caso, cobrar das empresas de que se cuida, concessionárias ou delegadas do Estado-membro para a prestaçāo de serviço público.

21. - Em face de todo o exposto, dou as seguintes respostas aos quesitos propostos na consulta:

1. cresce de fundamento jurídico, resultando, destarte, ilegal, como acima demonstrado, a cobrança pretendida pelo Departamento Nacional de Estradas de Rodagem - DNER, pelos Departamentos Estaduais de Estradas de Rodagem (DERs) de alguns Estados-mem-

1 Art. 150. I da Constituição do Brasil. 
bros, bem como por empresas privadas que adquiriram a concessão da exploração de rodovias, cobrança pelo uso, por empresas concessionárias de serviços públicos, de faixas de domínio de rodovias, sejam elas federais, estaduais ou municipais - assim como pelo uso de faixas de domínio de ferrovias;

2. [prejudicado];

3. não; se a empresa concessionária de distribuição de gás canalizado obteve junto aos órgãos competentes autorização para a construçāo de gasodutos e redes em faixas de domínio de rodovias ou ferrovias, a concessionária que, por força do contrato celebrado entre esta e o órgão cedente $[=$ poder conce- dente]. explora a rodovia/ferrovia não poderá impedir o início das obras:

4. [prejudicado];

5. não: o Município não pode, no âmbito de sua competência constitucional, cobrar remuneração, a qualquer título, pela instalação de redes de gás canalizado ou passagem de dutos no seu perímetro urbano.

É o que me parece

São Paulo, 20 de agosto de 1999

Eros Roberto Grau

Professor Titular da Faculdade de Direito da USP

Professor Visitante da Faculdade de Direito da Universidade de Montpellier I (França) [1995-1998] 